\title{
Supramolecular Structures Formed by Calix[8]arene Derivatives
}

\author{
Ganna Podoprygorina, ${ }^{\text {a) }}$ Jian Zhang, ${ }^{\text {b) }}$ Vasiliy Brusko, ${ }^{\text {a),d) }}$ Michael Bolte, ${ }^{\text {c) }}$ Andreas Janshoff ${ }^{\text {b) } *}$ \\ and Volker Böhmer ${ }^{\text {a)* }}$ \\ a) Abteilung Lehramt Chemie, Fachbereich Chemie und Pharmazie, Johannes Gutenberg-Universität, Duesbergweg \\ 10-14, D-55099 Mainz, Germany \\ b) Institut für Physikalische Chemie, Fachbereich Chemie und Pharmazie, Johannes Gutenberg-Universität, \\ Welderweg 11, D-55099 Mainz, Germany \\ c) Institut für Organische Chemie, Johann Wolfgang von Goethe Universität, Marie Curie-Straße 11, D-60439 \\ Frankfurt/Main, Germany \\ d) Permanent address: Chemical Department, Kazan State University, Kremlevskaya St. 18, 420008 Kazan, Russia
}

\section{Supporting Information}

\section{Experimental procedures}

2: A stirred solution of compound 1 ( $3 \mathrm{~g}, 2.128 \mathrm{mmol})$ in $80 \mathrm{ml}$ of chloroform was cooled down to $5{ }^{\circ} \mathrm{C}$ in ice bath. Then $8 \mathrm{ml}$ of glacial acetic acid and $10 \mathrm{ml}$ of fuming nitric acid (100\%) was added to the solution (the colour of the mixture was immediately changed from light yellow into dark-violet). The reaction mixture was stirred for 12 hours allowing to heat to room temperature. Then water was poured into the mixture and organic layer was separated and washed with water. After chloroform was removed in vacuo and methanol was added. A yellowish precipitate was filtered off, washed with methanol and dried. The crude product was refluxed in $100 \mathrm{ml}$ of chloroform for $30 \mathrm{~min}$ and cooled down to room temperature. The light yellow solid was filtered off and washed with chloroform to give after drying pure product 2 in $50 \%$ yield (1.428 g). m.p.: $>240{ }^{\circ} \mathrm{C}$ decomp. ${ }^{1} \mathrm{H}$ NMR (DMSO-d $6,300 \mathrm{MHz}$ ): 7.80 (s, ArH, $16 \mathrm{H}$ ), 4.19 (s, $\mathrm{ArCH}_{2} \mathrm{Ar}, 16 \mathrm{H}$ ), $3.66\left(\mathrm{~s},-\mathrm{OCH}_{3}, 24 \mathrm{H}\right)$.

3: A suspension of nitro calix[8]arene $2(0.390 \mathrm{~g}, 0.295 \mathrm{mmol})$ and $15 \mathrm{ml}$ of hydrazine hydrate in $\mathrm{THF} / \mathrm{EtOH}$ was refluxed for 24 hours in the presence of $\mathrm{Pd} / \mathrm{C}$. The end of reaction was controlled by TLC. Then the catalyst was filtered off and washed with $\mathrm{MeOH}: \mathrm{HCl}(80 \mathrm{ml}: 10 \mathrm{ml})$ to remove the rest of the product from catalyst. The solvent was removed under reduced pressure and $80 \mathrm{ml}$ of water and $5 \mathrm{ml}$ of $\mathrm{Et}_{3} \mathrm{~N}$ were added to residue. The light-brown precipitate was filtered off and washed with water and methanol giving 3 (0.192 g, 60\% yield). m.p.: $>370^{\circ} \mathrm{C}$ decomp. ${ }^{1} \mathrm{H}$ NMR 
(DMSO-d 6 , 400 MHz): 6.07 (s, ArH, 16 H), 4.56 (s, NH 2,16 H), 3.69 (s, $\left.\mathrm{ArCH}_{2} \mathrm{Ar}, 16 \mathrm{H}\right), 3.44$ (s, $\left.-\mathrm{OCH}_{3}, 24 \mathrm{H}\right)$.

4: To a solution of acid chloride of gallic acid tris-decylether $(0.028 \mathrm{~g}, 0.462 \mathrm{mmol})$ in $3 \mathrm{ml}$ of THF a suspension of amino compound $3(0.050 \mathrm{~g}, 0.0462 \mathrm{mmol})$ in $3 \mathrm{ml}$ of THF was added and the resulting mixture was stirred for $24 \mathrm{~h}$ in presence of an excess of $(i-\operatorname{Pr})_{2} \mathrm{NEt}$ at r.t. After $3 \mathrm{ml}$ of methanol was added to the reaction mixture. Then the solvent was removed under reduced pressure to dryness and the residue was recrystallized from ethyl acetate. The precipitate (gallic acid methylester) was filtered off, washed with ethyl acetate. The mother liquid was concentrated in vacuo, diluted with ethanol and left for 3-4 $\mathrm{h}$ in the fridge. A formed white solid was filtered off to give 4 in 50\% yield (0.130 g). m.p.: $204^{\circ} \mathrm{C} .{ }^{1} \mathrm{H}$ NMR (THF-d $8,400 \mathrm{MHz}$ ): 9.13 (s, NH, 8 H), 7.36 (s, $\mathrm{ArH}, 16 \mathrm{H}), 7.10$ (s, $\mathrm{ArH}, 16 \mathrm{H}), 3.90$ (m, $\left.\mathrm{ArCH}_{2} \mathrm{Ar},-\mathrm{OCH}_{2^{-}}, 64 \mathrm{H}\right), 3.47$ (s, - $-\mathrm{OCH}_{3}$, $24 \mathrm{H}$ ), 1.72 (m under THF, -O- $\left.\mathrm{CH}_{2}-\mathbf{C H}_{2}-\mathrm{CH}_{2}-\left(\mathrm{CH}_{2}\right)_{6}-\mathrm{CH}_{3}, 48 \mathrm{H}\right), 1.44$ (m, -O- $\mathrm{CH}_{2}-\mathrm{CH}_{2}-\mathbf{C H}_{2}-$ $\left.\left(\mathrm{CH}_{2}\right)_{6}-\mathrm{CH}_{3}, 48 \mathrm{H}\right), 1.28\left(\mathrm{~m},-\mathrm{O}-\left(\mathrm{CH}_{2}\right)_{3}-\left(\mathbf{C H}_{2}\right)_{6}-\mathrm{CH}_{3}, 288 \mathrm{H}\right), 0.88$ (br.t, - $\left.\mathrm{O}-\left(\mathrm{CH}_{2}\right)_{9}-\mathbf{C H}_{3}, 72 \mathrm{H}\right)$.

5: To a suspension of the amino compound $3(0.050 \mathrm{~g}, 0.0462 \mathrm{mmol})$ in $2 \mathrm{ml}$ of dry THF a solution of isocyanate (prepared from gallic acid tris-decylether $(0.410 \mathrm{~g}, 0.694 \mathrm{mmol})$ according to procedure described by Ninomiya, K.; Shioiri, T.; Yamada, S. Tetrahedron 1974, 30, 21512157) in $3 \mathrm{ml}$ of THF was added. The reaction was stirred for $24 \mathrm{~h}$ at r.t. Then $3 \mathrm{ml}$ of methanol was added into the solution. After the solvent was removed in vacuo the oily residue was suspended in $n$-hexane and left for $5 \mathrm{~h}$ in the fridge. The formed solid (urethane of gallic acid) was filtered off and washed with $n$-hexane. The solvent from mother liquid was evaporated under reduced pressure to dryness and the rest was precipitated from THF/MeOH to give product 5 in $34 \%$ yield $\left(0.093\right.$ g). m.p.: $>210^{\circ} \mathrm{C}$ decomp. ${ }^{1} \mathrm{H}$ NMR (DMSO-d $6,400 \mathrm{MHz}, 130^{\circ} \mathrm{C}$ ): 7.97 (s, NH, 8 H), 7.92 (s, NH, 8 H), 7.07 (s, ArH, 16 H), 6.66 (s, ArH, 16 H), 3.89 (m, $\mathrm{ArCH}_{2} \mathrm{Ar}$, $\left.\mathrm{OCH}_{2^{-}}, 64 \mathrm{H}\right), 3.45$ (s, - $\left.\mathrm{OCH}_{3}, 24 \mathrm{H}\right), 1.66\left(\mathrm{~m},-\mathrm{O}^{-} \mathrm{CH}_{2}-\mathrm{CH}_{2}-\mathrm{CH}_{2}-\left(\mathrm{CH}_{2}\right)_{6}-\mathrm{CH}_{3}, 48 \mathrm{H}\right), 1.42$ (m, $\left.\mathrm{O}-\mathrm{CH}_{2}-\mathrm{CH}_{2}-\mathbf{C H}_{2}-\left(\mathrm{CH}_{2}\right)_{6}-\mathrm{CH}_{3}, 48 \mathrm{H}\right), 1.29\left(\mathrm{~m},-\mathrm{O}-\left(\mathrm{CH}_{2}\right)_{3}-\left(\mathbf{C H}_{2}\right)_{6}-\mathrm{CH}_{3}, 288 \mathrm{H}\right), 0.86(\mathrm{~m},-\mathrm{O}-$ $\left.\left(\mathrm{CH}_{2}\right)_{9}-\mathbf{C H}_{3}, 72 \mathrm{H}\right)$. 
6a: The amino compound $3(0.200 \mathrm{~g}, 0.0925 \mathrm{mmol})$ and 1,8-naphtalic anhydride $(0.366 \mathrm{~g}, 0.925$ $\mathrm{mmol})$ were refluxed in $3 \mathrm{ml}$ of dry pyridine in the presence of $\mathrm{Zn}(\mathrm{OAc})_{2}(0.370 \mathrm{~g}, 0.925 \mathrm{mmol})$ for $48 \mathrm{~h}$. After cooling down to room temperature the reaction mixture was poured into cold $10 \%$ $\mathrm{HCl}$ solution. A thin brown solid was filtered off, washed with water and methanol. After suspending in $\mathrm{CH}_{3} \mathrm{CN} / \mathrm{THF}$, filtration and drying 6a was given in $75 \%$ yield (0.466 g). m.p.: $>420^{\circ} \mathrm{C}$ decomp. ${ }^{1} \mathrm{H}$ NMR (DMSO-d $6,400 \mathrm{MHz}, 70^{\circ} \mathrm{C}$ ): 8.22 (d, ArH, $16 \mathrm{H}, J=8.3 \mathrm{~Hz}$ ), 8.07 (d, ArH, $16 \mathrm{H}, J=6.8 \mathrm{~Hz}), 7.64$ (m, ArH, $16 \mathrm{H}), 7.02$ (s, ArH, $16 \mathrm{H}), 4.11$ (s, $\left.\mathrm{ArCH}_{2} \mathrm{Ar}, 16 \mathrm{H}\right), 3.64$ (s, $\left.-\mathrm{OCH}_{3}, 24 \mathrm{H}\right)$.

6b: The compound $\mathbf{6 b}$ was given by cleavage of methyl groups from octamethoxy compound $\mathbf{6 a}$ $(0.358 \mathrm{~g}, 0.142 \mathrm{mmol})$ in $7 \mathrm{ml}$ of dichloromethane by an addition of $\mathrm{BBr}_{3}(1 \mathrm{M}$ in dichloromethane, $3 \mathrm{ml}, 3 \mathrm{mmol}$ ) at $-78^{\circ} \mathrm{C}$ under nitrogen. After for $4 \mathrm{~h}$ of stirring the resulting mixture was allowed to warm slowly to r.t. and then was stirred at r.t. over $12 \mathrm{~h}$. Water was added to hydrolyze the excess of $\mathrm{BBr}_{3}$ and the solution was stirred for further $20 \mathrm{~min}$. Then it was neutralized with aqueous concentrated ammonia $(10 \mathrm{ml})$. The precipitate was filtered off and washed with methanol and $\mathrm{CH}_{3} \mathrm{CN}$ to give after drying $0.310 \mathrm{~g}$ of pure product $\mathbf{6 b}$ (90\% yield). m.p.: $>350^{\circ} \mathrm{C}$ decomp. ${ }^{1} \mathrm{H}$ NMR (DMSO-d $6,400 \mathrm{MHz}, 70^{\circ} \mathrm{C}$ ): 4.06 (s, $\mathrm{ArCH}_{2} \mathrm{Ar}, 16 \mathrm{H}$ ), 6.99 (s, ArH, 16 H), 7.78 (tr, ArH, 16 H, j = 7.6 Hz), 8.11-8.60 (overlapped, ArH, $32 \mathrm{H}$ ). 